\title{
How Irrigation Water Affects the Yield and Nutritional Quality of Maize (Zea mays L.) in a Temperate Climate
}

\author{
Branka Kresović ${ }^{1}$, Boško Gajić ${ }^{2 *}$, AngelinaTapanarova², Goran Dugalić ${ }^{3}$ \\ 'Zemun Polje Maize Research Institute, Slobodana Bajića 1, 11185 Belgrade, Serbia \\ ${ }^{2}$ University of Belgrade, Faculty of Agriculture, Institute of Soil and Melioration, \\ Nemanjina 6, 11080 Belgrade, Serbia \\ ${ }^{3}$ University of Kragujevac, Faculty of Agronomy Čačak, \\ Cara Dušana 34, 32000 Čačak, Serbia
}

Received: 19 July 2017

Accepted: 26 August 2017

\begin{abstract}
Soil water deficit has an adverse effect on crop productivity and is one of the main limiting factors of global food security. Field experiments were conducted in Vojvodina, Serbia, to expand and improve knowledge about the effects of different levels of irrigation on maize grain yield and quality. The studied irrigation treatments were: full irrigation $\left(\mathrm{I}_{100}\right), 75 \%\left(\mathrm{I}_{75}\right)$ and $50 \%\left(\mathrm{I}_{50}\right)$ of $\mathrm{I}_{100}$, and no irrigation $\left(\mathrm{I}_{0}\right)$-rainfed. The irrigation level affects maize grain yield; protein, starch, and oil content; and mineral composition. The results show that that yield decreases with increasing water deficit in three study years. On average, full irrigation results in the highest oil content and rainfed conditions in the lowest. The starch content increases and the oil content decreases with decreasing irrigation. Irrigation significantly increases the concentrations of $\mathrm{K}, \mathrm{Mg}, \mathrm{Fe}, \mathrm{Mn}$, and $\mathrm{Zn}$, and reduces the $\mathrm{Ca}$ concentration compared to the rainfed treatment. A $25 \%$ water deficit $\left(\mathrm{I}_{75}\right)$ has a positive effect on certain maize grain nutrients and the yield is significantly reduced. The highest grain yield and oil content are achievable with full irrigation. For good nutrientional quality of maize, treatment $\mathrm{I}_{75}$ can be proposed under similar soil and climate conditions.
\end{abstract}

Keywords: water saving, protein content, oil content, starch content, macro- and micromineral concetrations

\section{Introduction}

Maize (Zea mays L.) is one of the most important crops for human and animal consumption and is grown for both grain and silage. It is now increasingly being used for the production of bioethanol. In global terms,

*e-mail: bonna@agrif.bg.ac.rs it is the third most important nutritional crop after wheat and rice. These three crops together are the major contributors to human and animal food security. Total area coverage and output of maize in 2012 in Serbia was 1.2 Mha and $6.2 \mathrm{Tg}$, respectively. Most of the maize is produced in the province of Vojvodina in the northern lowlands of Serbia that are part of the Pannonian Plain. Droughts during the growing season are frequent in this region and are caused by climate change [1]. As a result, 
irrigation is increasingly applied to stabilize and increase maize yields. Decreasing the availability of freshwater resources is one of the major challenges of food and fiber production in many parts of the world, including Vojvodina. In such conditions the productivity and quality of maize depend strongly on irrigation. In many agricultural regions such as Vojvodina the availability and quality of irrigation water are on the decline due to climate change and growing water demand of other users (e.g., industry, environment, drinking water supply, recreation, mining, etc.). Irrigation water is becoming an increasingly limited resource in many parts of southern Europe, requiring proper irrigation treatments to increase water use efficiency and profits. In this context, limited irrigation is proposed as a useful strategy in areas where water is one of the major constraints of plant production. Foroud et al. [2] stressed that it is important to understand and predict the effect of different levels of water deficit on maize grain yield and quality in order to improve irrigation management especially when the water supply is limited.

A number of researchers have reported on the effect of deficit irrigation on maize grain yield and quality. Ge et al. [3] determined that maize grown under moderate and strong water stress conditions recorded a considerably lower yield compared to full irrigation. Limited irrigation practices affect not only grain yield, but the quality parameters as well, such as protein, starch, oil, cellulose, ash content, and mineral composition. Thitisaksakul et al. [4] have shown that drought can reduce the starch content and increase the protein content of many crops. An experiment conducted by Tarighaleslami et al. [5] found that the protein content of maize grain decreased with increasing water stress.

Recently researchers found that water stress is important for irrigation and soils. Also, conducting similar studies on different species and the different origins of the species determined to be resistant to drought in wider fields carries great importance in terms of identifying the species most resistant to drought, and in this way preparing healthy landscape planning in arid fields [6-9].
An experiment performed by Ge et al. [3] showed that strong water stress resulted in a statistically significant increase in the concentrations of $\mathrm{N}, \mathrm{Ca}, \mathrm{Mg}, \mathrm{Cu}$, and $\mathrm{Zn}$ in maize grain by about $12 \%, 28 \%, 11 \%, 18 \%$, and $33 \%$, respectively, compared to full-watered conditions. However, the same experiment also revealed a significant $(P<0.05)$ decrease in the starch, $\mathrm{P}$, and $\mathrm{K}$ contents and maize grain yield by some $28 \%, 17 \%, 17 \%$, and $375 \%$, respectively, under strong stress conditions compared to full-watered conditions (no stress).

Information about the nutritional value and components of fresh and processed foods are essential for planning in a number of sectors such as agriculture, health, nutrition, education, industry, and food commerce [10]. The appropriate water-saving irrigation practices are urgently sought to maintain sustainable growth in cereal production [11].

The present research was undertaken to determine the effects of different irrigation levels on yields and a number of nutrients, such as maize grain protein, oil and starch content, and the concentrations of phosphorus (P), potassium $(\mathrm{K})$, calcium $(\mathrm{Ca})$, magnesium $(\mathrm{Mg})$, iron $(\mathrm{Fe})$, manganese $(\mathrm{Mn})$, copper $(\mathrm{Cu})$, and zinc $(\mathrm{Zn})$ in three growing seasons under ecological conditions that exist in Vojvodina. Suitable irrigation scheduling and sprinkler irrigation are recommended to maize producers in the region.

\section{Materials and Methods}

Site and Climate

The research was conducted in the growing seasons of 2012, 2013, and 2014 in an experimental field comprised of silty-clay-carbonate chernozem belonging to the Maize Research Institute of Zemun Polje (4452'00' N; $20^{\circ} 19^{\prime} 00^{\prime}$ E, alt. $81 \mathrm{~m}$ ) near Belgrade, Serbia. The climate in the region is moderately continental, characterized by cold winters and warm dry summers as well as variable and unevenly distributed rainfall during the growing

Table 1. Difference between experimental field growing season air temperatures and precipitation, and perennial averages (1993-2013).

\begin{tabular}{|c|c|c|c|c|c|c|c|c|}
\hline \multirow{2}{*}{ Month } & \multicolumn{4}{|c|}{ Temperature $\left({ }^{\circ} \mathrm{C}\right)$} & \multicolumn{4}{c|}{ Precipitation (mm) } \\
\cline { 2 - 10 } & 20 -yr Avg. & 2012 & 2013 & 2014 & 20 -yr Avg. & 2012 & 2013 & 2014 \\
\hline April & 12.0 & 1.3 & 0.2 & 1.2 & 59.7 & -32.4 & 33.4 & -28.6 \\
\hline May & 17.2 & 1.1 & -1.4 & 1.6 & 55.6 & -15.9 & -22.3 & -13.6 \\
\hline June & 20.1 & 2.2 & -1.3 & 2.4 & 95.4 & -59.1 & 48.2 & -32.4 \\
\hline July & 21.8 & 0.8 & 1.0 & 2.1 & 56.7 & -10.5 & -29.4 & -38.0 \\
\hline Aug. & 22.2 & 0.6 & -2.6 & 1.5 & 61.8 & -42.1 & 47.2 & -10.2 \\
\hline Sept. & 18.0 & -1.4 & 0.5 & -2.9 & 55.0 & 0.4 & -44.2 & 18.0 \\
\hline April-Sept. & 18.6 & 0.8 & -0.6 & 1.0 & 384.1 & -159.6 & 32.9 & -104.8 \\
\hline Annual & 11.9 & 11.4 & 12.9 & 12.23 & 638.0 & 661.4 & 670.1 & 486.5 \\
\hline
\end{tabular}


season. Table 1 shows the climate variables during the study period and growing season (April to September) perennial averages.

\section{Experimental Setup}

The experiment was of a random block design, with four replications and four irrigation regimes. The surface area of the plots was $150 \mathrm{~m}^{2}$ (7.14 m wide x $21 \mathrm{~m}$ long) comprised of 30 rows. The maize hybrid ZP SC 684 (FAO 600 ) was grown. The distance between the rows was 0.70 $\mathrm{m}$ and within the rows $0.26 \mathrm{~m}$. Identical agro-technical measures were implemented, except for the amount of irrigation water. Irrigation water was withdrawn from an $80 \mathrm{~m}$-deep well located in the experimental field. Irrigation water was applied by means of a portable sprinkler system.

Comparisons were made between three irrigation treatments: $I_{100}, I_{75}$, and $I_{50}$, replenishing $100 \pm 5 \%$, $75 \pm 5 \%$, and $50 \pm 5 \%$ of the water accessible to the plants (difference in stored soil water, between field capacity and the wilting point), and rainfed treatment $\left(\mathrm{I}_{0}\right)$. The plants were watered when, during the full irrigation treatment $\left(\mathrm{I}_{100}\right), 40 \%$ of accessible soil water in the $0.90 \mathrm{~m}$-deep top layer of soil was used up. Irrigation water amounts applied to the experimental treatments are presented in Table 2.

\section{Determining Grain Yield and Production of Maizemeal}

At physiological maturity (18 October 2012, 12 October 2013, and 13 October 2014), the middle ( $15^{\text {th }}$ and $\left.16^{\text {th }}\right)$ rows of each experimental plot were hand-picked. The grain was removed manually and weighed. Grain yield was determined at $13 \%$ moisture content. The yield, protein content, starch content, oil content, and mineral composition of maize grain were determined after each harvest.

\section{Preparation of Samples for Chemical Analysis}

For chemical analysis of maize grain, 15 ears of maize with fully developed grains were arbitrarily selected from each parcel, picked, and taken to the laboratory. The grains were manually removed from each ear and dried at $75^{\circ} \mathrm{C}$ to a constant weight. They were then ground in a Wiley mill with a No. 20 stainless steel screen up to a particle size of $850 \mu \mathrm{m}$ and the maizemeal stored in polyethylene containers in darkness at $4^{\circ} \mathrm{C}$ until chemical analysis.

\section{Chemical Analyses}

Protein content of the maizemeal was determined by Kjeldahl method, oil content by Soxhlet extraction method [12], and starch content by Ewers polarimetric

Table 2. Seasonal irrigation water supply, maize grain yield, and protein, starch, and oil contents under different irrigation levels.

\begin{tabular}{|c|c|c|c|c|c|c|}
\hline Years & $\begin{array}{l}\text { Irrigation } \\
\text { levels }\end{array}$ & $\begin{array}{l}\text { Irrigation } \\
(\mathrm{mm})\end{array}$ & $\begin{array}{l}\text { Grain yield } \\
(\mathrm{t} / \mathrm{ha})\end{array}$ & $\begin{array}{l}\text { Protein content } \\
\qquad(\mathrm{g} / \mathrm{kg})\end{array}$ & $\begin{array}{l}\text { Starch content } \\
(\mathrm{g} / \mathrm{kg})\end{array}$ & $\begin{array}{l}\text { Oil content } \\
(\mathrm{g} / \mathrm{kg})\end{array}$ \\
\hline \multirow{4}{*}{2012} & $\mathrm{I}_{100}$ & 100 & $14.59 \mathrm{a}^{*}$ & $87.9 \mathrm{c}$ & $712.0 \mathrm{c}$ & $50.3 \mathrm{a}$ \\
\hline & $\mathrm{I}_{75}$ & 70 & $12.46 \mathrm{~b}$ & $90.6 \mathrm{a}$ & $712.7 \mathrm{c}$ & $50.2 \mathrm{a}$ \\
\hline & $\mathrm{I}_{50}$ & 0 & $11.41 \mathrm{c}$ & $87.4 \mathrm{~b}$ & $718.0 \mathrm{a}$ & $49.9 \mathrm{a}$ \\
\hline & $\mathrm{I}_{0}$ & 0 & $11.14 \mathrm{c}$ & $87.3 \mathrm{~b}$ & $717.3 \mathrm{~b}$ & $50.0 \mathrm{a}$ \\
\hline \multirow{4}{*}{2013} & $\mathrm{I}_{100}$ & 155 & $16.33 \mathrm{a}$ & $90.2 \mathrm{c}$ & $713.5 \mathrm{~d}$ & $52.6 \mathrm{a}$ \\
\hline & $\mathrm{I}_{75}$ & 115 & $14.54 \mathrm{~b}$ & $96.9 \mathrm{a}$ & $715.4 \mathrm{c}$ & $49.0 \mathrm{~b}$ \\
\hline & $\mathrm{I}_{50}$ & 95 & $13.51 \mathrm{c}$ & $95.3 \mathrm{~b}$ & $718.3 \mathrm{~b}$ & $48.0 \mathrm{c}$ \\
\hline & $\mathrm{I}_{0}$ & 0 & $10.74 \mathrm{~d}$ & $87.8 \mathrm{~d}$ & $733.1 \mathrm{a}$ & $45.3 \mathrm{~d}$ \\
\hline \multirow{4}{*}{2014} & $\mathrm{I}_{100}$ & 280 & $14.31 \mathrm{a}$ & $93.1 \mathrm{c}$ & $711.6 \mathrm{~d}$ & $48.2 \mathrm{a}$ \\
\hline & $\mathrm{I}_{75}$ & 200 & $13.65 \mathrm{~b}$ & $99.8 \mathrm{a}$ & $712.9 \mathrm{c}$ & $47.7 \mathrm{~b}$ \\
\hline & $\mathrm{I}_{50}$ & 145 & $12.69 \mathrm{c}$ & $94.9 \mathrm{~b}$ & $717.9 \mathrm{~b}$ & $47.5 \mathrm{~b}$ \\
\hline & $\mathrm{I}_{0}$ & 0 & $8.73 \mathrm{~d}$ & $92.6 \mathrm{~d}$ & $725.3 \mathrm{a}$ & $46.9 \mathrm{c}$ \\
\hline \multirow{4}{*}{$\begin{array}{c}\text { 3-year } \\
\text { average }\end{array}$} & $\mathrm{I}_{100}$ & 178 & $15.08 \mathrm{a}$ & $90.4 \mathrm{c}$ & $712.4 \mathrm{~d}$ & $50.4 \mathrm{a}$ \\
\hline & $\mathrm{I}_{75}$ & 128 & $13.55 \mathrm{~b}$ & $95.8 \mathrm{a}$ & $713.7 \mathrm{c}$ & $49.0 \mathrm{~b}$ \\
\hline & $\mathrm{I}_{50}$ & 80 & $12.54 \mathrm{c}$ & $92.5 \mathrm{~b}$ & $718.1 \mathrm{~b}$ & $48.5 \mathrm{~b}$ \\
\hline & $\mathrm{I}_{0}$ & 0 & $10.20 \mathrm{~d}$ & $89.2 \mathrm{~d}$ & $725.2 \mathrm{a}$ & $47.4 \mathrm{c}$ \\
\hline
\end{tabular}

* Means followed by similar letters in each column are not significantly different as statistically $(P \leq 0.05)$. 
method [13]. Phosphorus content of the maizemeal was determined by the colorimetric method, $\mathrm{K}$ content by flame photometry, calcium and magnesium contents by EDTA titration method, and iron, manganese, copper, and zinc contents were determined by atomic absorption spectrometry [12]. All chemical analyses of maize grain were repeated three times and the results presented based on dry weight.

\section{Statistical Analysis}

The results were statistically analyzed by applying one-way ANOVA. Differences between averages were detected by the LSD test at a probability level of 5\%. Pearson's coefficients of correlation between maize grain yield and quality parameters were also determined. All statistical analyses were conducted using SPSS software for Windows, version 14.0 (SPSS Inc., Chicago, IL, USA).

\section{Results and Discussion}

\section{Response of Grain Yield to Irrigation Treatments}

Maize grain yield increased in response to irrigation, but the rate of increase varied between years (Table 2). The plants that received less irrigation recorded a considerably smaller yield. The rainfed $\left(\mathrm{I}_{0}\right)$ maize measured the lowest grain yield. There was no statistically significant difference between treatments $\mathrm{I}_{50}$ and $\mathrm{I}_{0}$ in 2012 - the rainiest year. Compared to the rainfed maize, treatments $\mathrm{I}_{50}, \mathrm{I}_{75}$, and $\mathrm{I}_{100}$ increased grain yields on average by $23 \%, 33 \%$, and $48 \%$, respectively. The deficit irrigation treatments resulted in considerably lower yields than full irrigation $\left(\mathrm{I}_{100}\right)$. According to three-year averages, the highest yield $(15,080 \mathrm{~kg} / \mathrm{ha})$ was achieved with the $\mathrm{I}_{100}$ treatment. The yields in treatments $\mathrm{I}_{75}$ and $I_{50}$ significantly decreased (13,550 and $\left.12,540 \mathrm{~kg} / \mathrm{ha}\right)$ with decreasing amounts of water added by irrigation. Considering all irrigation levels, treatment $\mathrm{I}_{75}$ can be accepted as an alternative approach in the case of limited water resources for irrigation, with a considerable yield decrease. The lower grain yield of maize under water stress may be primarily due to reducing $\mathrm{CO}_{2}$ assimilation area, net assimilation rate, leaf number and total leaf area, and yield components (ear size, number of grains per ear, and grain mass) [14]. According to Dolferus et al. [15], the grain number is the vital yield component that is directly associated with increased grain yield in cereal crops. Bhimireddy et al. [16] reported that grain yield of no-till maize increased with increases in water input from a $75 \%$ pan evaporation (PE) to a $100 \% \mathrm{PE}$ irrigation schedule in drip irrigation, but could not reach the level of significance at $125 \% \mathrm{PE}$ in the semi-arid environment of India. Similar to the results of the present study, Aydinsakir et al. [17] reported the highest grain yields with full irrigation $\left(\mathrm{I}_{100}\right)$ and the lowest with no irrigation $\left(\mathrm{I}_{0}\right)$. A reduction in maize grain yield due to lack of soil water depends on many factors, such as soil, climate conditions during the growing season, drought severity and duration, stage of growth, and hybrid sensitivity to soil drought [18].

\section{Protein}

Protein content was affected by the level of irrigation and varied considerably between the years. As shown in Table 2, the protein content of maize grain was significantly lower in treatments that provided the most $\left(\mathrm{I}_{100}\right)$ and the least $\left(\mathrm{I}_{50}\right)$ irrigation water. The highest protein content $(95.8 \mathrm{~g} / \mathrm{kg}$ on average) was noted in the case of treatment $\mathrm{I}_{75}$. This showed that the protein content decreased if the amount of irrigation water was above or below a certain level, that is to say, proper water deficit (treatment $\mathrm{I}_{75}$ ) was benefit to protein formation of maize grain in Vojvodina. The relatively dry growing season of 2014 resulted in a significantly higher protein content in all treatments. The high protein content under water stress can be ascribed to the increase in the activities of glutamate synthase and glutamine synthetase, which are involved in nitrogen metabolism by promoting nitrogen accumulation and increasing the protein content of maize grains [19].

Ertek and Kara [18] studied the effects of different irrigation levels on the yield and quality of sweet corn in Turkey and reported results similar to the present study, namely that increasing irrigation decreased the protein content of maize grain. Contrary to the findings of the present research, Aydinsakir et al. [17] determined that in the ecological conditions in Antalya, Turkey, the protein content of maize grain was the highest with full irrigation $\left(\mathrm{I}_{100}\right)$, and significantly lower with deficit irrigation and under rainfed conditions $\left(\mathrm{I}_{0}\right)$. Since protein is an important aspect of maize grain production, the irrigation level for maize in the agro-ecological environment of Vojvodina should be $\mathrm{I}_{75}$.

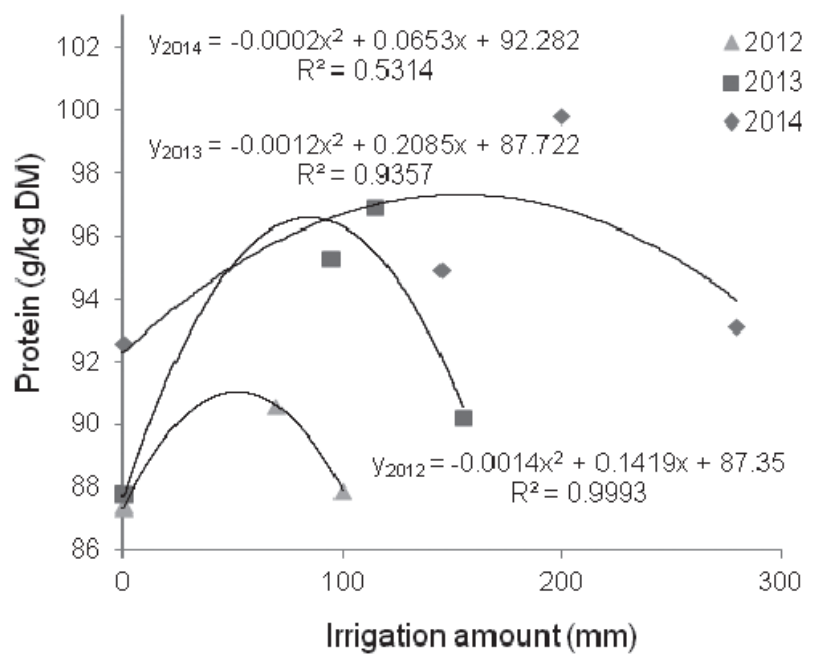

Fig. 1. Relationship between the content of protein in maize grains and amount of irrigation water. 


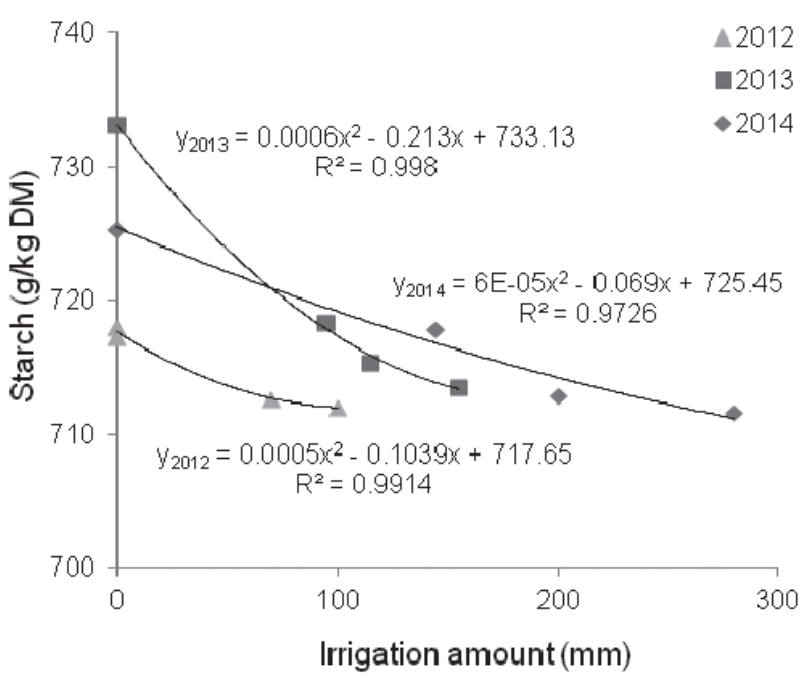

Fig. 2. Relationship between the content of starch in maize grains and amount of irrigation water.

In all three years of our research significant $(P<0.05)$ polynomial correlations were established between the amount of water added by irrigation and the protein content of maize grain (Fig. 1).

\section{Starch}

As shown in Table 2, the irrigation treatments had a significant effect on the starch content in all three study years, meaning that the rate of grain filling differed between the treatments. In the present research, the average values of starch content gradually increased with increasing irrigation water deficit, indicating that the grain filling rate was similar between the rainfed (nonirrigated) treatment and irrigated treatments. The increase was not large but statistically very significant $(P<0.05)$. One major reason for these changes could be alterations in starch biosynthetic enzyme activity and the accumulation of starch in grain. The conclusion is that irrigation might result in qualitative and/or quantitative differences in the rate of grain carbohydrate metabolism, as well as endosperm changes that reduce the rate of starch synthesis. Zhao et al. [20] reported that mild drought increased and that a large water deficit decreased the starch content. According to Thitisaksakul et al. [4], water stress during grain development can result in a reduced starch content due to changes in the enzyme activity responsible for starch biosynthesis.

Research conducted by Lu et al. [21] in China showed that water deficit had no effect on the starch content of fresh waxy maize. Liu et al. [22] reported that the starch content of the grain samples of maize grown with less irrigation was $3.0 \%$ smaller than with high irrigation levels.

Significant $(P<0.05)$ polynomial correlations of the second order were established between the maize grain starch content and the amount of water added by irrigation in all three study years (Fig. 2).
Oil

Statistical analysis revealed that the irrigation levels had a statistically significant $(P<0.05)$ effect on maize grain oil content in all three study years (Table 2). Treatment $\mathrm{I}_{100}$ recorded the highest oil content $(50.4 \mathrm{~g} / \mathrm{kg}$ on average), followed by treatments $I_{75}$ (avg. $49.0 \mathrm{~g} / \mathrm{kg}$ ), $\mathrm{I}_{50}$ (avg. $48.5 \mathrm{~g} / \mathrm{kg}$ ), and $\mathrm{I}_{0}$ (avg. $47.4 \mathrm{~g} / \mathrm{kg}$ ). The results clearly indicate that in this research full irrigation $\left(\mathrm{I}_{100}\right)$ increased the maize grain oil content and that the lower irrigation levels resulted in a considerable reduction, that is to say, water deficit during the growing season of maize can result in a decrease in oil contents in grains. The above results also indicated that maize grains in our study had significantly higher oil and lower protein contents from maize exposed to high soil moisture status throughout the growing period of the crop. The oil content was significantly higher in the relatively wet season (2012) than in the dry seasons (2013 and 2014). These results are consistent with those of Ali et al. [23], who reported that a water deficit significantly reduced the grain oil content of two maize cultivars grown under Youslava (Pakistan) environmental conditions. Other authors have reported different results. For example, Liu et al. [22] did not note any significant difference in the grain oil content of maize grown with different levels of irrigation. Considering the effect of drought stress on the grain oil content of summer maize, Ge et al. [3] stated that moderate drought increased and that strong drought decreased the oil content. One of the possible reasons for these inconsistent findings is that maize oil is an inheritable feature and that genetic factors have a greater effect than the external environment. Some earlier studies have shown that the chemical composition of seed depends on the type of cultivar, amount of irrigation water used for production, and the period taken to full maturity of cultivars [23]. Furthermore, in some earlier studies it has been reported that soil moisture deficit can affect seed chemical composition by reducing

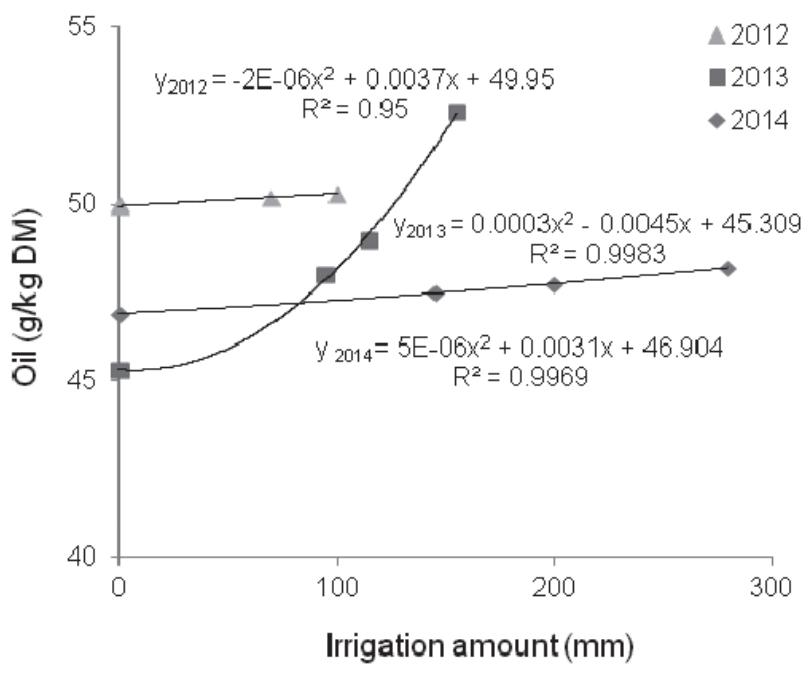

Fig. 3. Relationship between the content of oil in maize grains and amount of irrigation water. 
Table 3. Effect of different irrigation levels on the concentrations of select maize grain macrominerals.

\begin{tabular}{|c|c|c|c|c|c|}
\hline Years & $\begin{array}{c}\text { Irrigation } \\
\text { levels }\end{array}$ & $\begin{array}{c}\mathrm{P} \\
(\mathrm{g} / \mathrm{kg})\end{array}$ & $\begin{array}{c}\mathrm{K} \\
(\mathrm{g} / \mathrm{kg})\end{array}$ & $\begin{array}{c}\mathrm{Ca} \\
(\mathrm{mg} / \mathrm{kg})\end{array}$ & $\begin{array}{c}\mathrm{Mg} \\
(\mathrm{mg} / \mathrm{kg})\end{array}$ \\
\hline \multirow{4}{*}{2012} & $\mathrm{I}_{100}$ & $2.6 \mathrm{a}^{*}$ & $3.9 \mathrm{a}$ & $10.2 \mathrm{~b}$ & $116.8 \mathrm{~b}$ \\
\hline & $\mathrm{I}_{75}$ & $2.9 \mathrm{a}$ & $3.7 \mathrm{~b}$ & $8.1 \mathrm{~b}$ & $135.4 \mathrm{a}$ \\
\hline & $\mathrm{I}_{50}$ & $1.9 \mathrm{a}$ & $3.9 \mathrm{a}$ & $10.0 \mathrm{~b}$ & $112.3 \mathrm{c}$ \\
\hline & $\mathrm{I}_{0}$ & $2.0 \mathrm{a}$ & $3.7 \mathrm{~b}$ & $22.1 \mathrm{a}$ & $109.3 \mathrm{c}$ \\
\hline \multirow{4}{*}{2013} & $\mathrm{I}_{100}$ & $2.3 \mathrm{a}$ & $4.4 \mathrm{a}$ & $9.0 \mathrm{~b}$ & $121.9 \mathrm{~b}$ \\
\hline & $\mathrm{I}_{75}$ & $2.8 \mathrm{a}$ & $3.8 \mathrm{a}$ & $9.5 \mathrm{~b}$ & $128.9 \mathrm{a}$ \\
\hline & $\mathrm{I}_{50}$ & $2.1 \mathrm{a}$ & $4.0 \mathrm{a}$ & $11.4 \mathrm{~b}$ & $109.7 \mathrm{c}$ \\
\hline & $\mathrm{I}_{0}$ & $2.2 \mathrm{a}$ & $3.6 \mathrm{~b}$ & $23.0 \mathrm{a}$ & $116.1 \mathrm{c}$ \\
\hline \multirow{4}{*}{2014} & $\mathrm{I}_{100}$ & $2.5 \mathrm{a}$ & $4.6 \mathrm{a}$ & $8.5 \mathrm{~b}$ & $119.5 \mathrm{~b}$ \\
\hline & $\mathrm{I}_{75}$ & $2.7 \mathrm{a}$ & $4.1 \mathrm{a}$ & $9.6 \mathrm{~b}$ & $130.8 \mathrm{a}$ \\
\hline & $\mathrm{I}_{50}$ & $2.4 \mathrm{a}$ & $4.2 \mathrm{a}$ & $9.5 \mathrm{~b}$ & $113.9 \mathrm{c}$ \\
\hline & $\mathrm{I}_{0}$ & $2.5 \mathrm{a}$ & $3.5 \mathrm{~b}$ & $21.8 \mathrm{a}$ & $111.5 \mathrm{c}$ \\
\hline \multirow{4}{*}{$\begin{array}{c}\text { 3-year } \\
\text { average }\end{array}$} & $\mathrm{I}_{100}$ & $2.5 \mathrm{a}$ & $4.3 \mathrm{a}$ & $9.2 \mathrm{~b}$ & $119.4 \mathrm{~b}$ \\
\hline & $\mathrm{I}_{75}$ & $2.8 \mathrm{a}$ & $3.9 \mathrm{~b}$ & $9.1 \mathrm{~b}$ & $131.7 \mathrm{a}$ \\
\hline & $\mathrm{I}_{50}$ & $2.1 \mathrm{a}$ & $4.0 \mathrm{~b}$ & $10.3 \mathrm{ab}$ & $112.0 \mathrm{c}$ \\
\hline & $\mathrm{I}_{0}$ & $2.2 \mathrm{a}$ & $3.6 \mathrm{c}$ & $22.3 \mathrm{a}$ & $112.3 \mathrm{c}$ \\
\hline
\end{tabular}

${ }^{*}$ Means followed by similar letters in each column are not significantly different as statistically $(P \leq 0.05)$.

$\mathrm{CO}_{2}$ assimilation or through an alteration in the metabolic processes of seed chemical composition [23].

In the present study, significant polynomial correlations of the second order were established between maize grain oil content and the amount of irrigation water (Fig. 3). Yazar et al. [24] have reported similar findings in this regard.

\section{Mineral Composition of Maize Grains}

The mineral composition of maize grain is an important parameter that needs to be considered in human nutrition. Maize grain is an excellent and relatively inexpensive source of certain minerals, especially in underdeveloped countries. As shown in Table 3, irrigation had a significant effect on the concentrations of macrominerals, such as $\mathrm{K}, \mathrm{Ca}$, and $\mathrm{Mg}$, as opposed to $\mathrm{P}$, where there was no statistically significant impact. The rainfed $\left(\mathrm{I}_{0}\right)$ maize measured a significantly $(P<0.05)$ lower concentration of $\mathrm{K}$ than irrigated maize. The highest concentration of $\mathrm{K}$ was noted in treatment $\mathrm{I}_{100}$, but compared to the other irrigation treatments there were no statistically significant differences. The largest water deficit $\left(\mathrm{I}_{0}\right)$ resulted in a significant increase in $\mathrm{Ca}$, relative to the irrigation treatments. However, as in the case of $\mathrm{K}$, there were no statistically significant differences in $\mathrm{Ca}$ concentrations of maize grain between the irrigation treatments. Irrigation significantly $(P<0.05)$ increased the concentration of $\mathrm{Mg}$ in the case of treatments $\mathrm{I}_{75}$ and $\mathrm{I}_{100}$, compared to rainfed conditions $\left(\mathrm{I}_{0}\right)$ and $\mathrm{I}_{50}$ treatment. There were no statistically significant differences between the latter two $\left(\mathrm{I}_{0}\right.$ and $\left.\mathrm{I}_{50}\right)$. These results indicate that soil drought increased the concentration of $\mathrm{Ca}$, but had an adverse effect on the concentrations of $\mathrm{K}$ and $\mathrm{Mg}$ of the maize grown in the study area. The present research revealed that the concentrations of $\mathrm{K}$ and $\mathrm{Mg}$ were more sensitive to soil drought than the concentrations of $\mathrm{Ca}$ and $\mathrm{P}$. The lower concentrations of $\mathrm{K}$ in the three waterstress treatments, relative to full irrigation $\left(\mathrm{I}_{100}\right)$, might be attributed to evidence that the availability of $\mathrm{K}$ increases considerably with increasing soil water content. Ge et al. [3] pointed out that strong water stress $(40 \pm 5 \%$ of full-watered) significantly $(P<0.05)$ increased the maize grain concentrations of $\mathrm{Ca}, \mathrm{Mg}, \mathrm{Cu}$, and $\mathrm{Zn}$, compared to full-watered. However, contrary to the results reported in the present paper, Ge et al. [3] determined a significant $(P<0.05)$ decrease in the concentrations of $\mathrm{P}$ and $\mathrm{K}(16.5 \%$ and $16.7 \%$, respectively) in high water-stress treatments relative to full-watered.

Similar to macrominerals, the composition of maize grain microminerals varied in a non-uniform manner relative to the different irrigation levels (Table 4). In general, treatments $\mathrm{I}_{75}$ and $\mathrm{I}_{0}$ recorded the highest and lowest concentrations, respectively, of Fe, $\mathrm{Mn}$, and $\mathrm{Zn}$. The maize that received the largest amount of irrigation water $\left(\mathrm{I}_{100}\right)$ had the highest concentration of $\mathrm{Cu}$ in the grain; the order was $\mathrm{I}_{100}>\mathrm{I}_{0}>\mathrm{I}_{75}>\mathrm{I}_{50}$. The reduced uptake of $\mathrm{K}, \mathrm{Fe}$, $\mathrm{Mn}, \mathrm{Cu}$, and $\mathrm{Zn}$ from the soil (in treatments $\mathrm{I}_{0}$ and $\mathrm{I}_{50}$ ) was attributed to water stress, given that water plays a major role in their mobilization. These results are contrary to literature sources. For example, Ge et al. [3] showed that strong water stress ( $40 \pm 5 \%$ of full-watered) significantly increased $(P<0.05)$ maize grain concentrations of $\mathrm{Cu}$ and $\mathrm{Zn}$ compared to full-watered. Unlike the results of the present study, Oktem [25] reported that sweetcorn grain concentrations of $\mathrm{Fe}, \mathrm{Zn}$, and $\mathrm{Cu}$ decreased significantly $(P<0.01)$ as the soil water deficit increased, in two study years. The reason for the difference between the present results and the other two studies could be a different composition of macro- and microelements and their combinations in the soils, as well as different properties of the soils. Genetic and ecological conditions and farming practices affect the quality and chemical composition of maize grain [26] and the concentration of minerals [27].

The considerable differences in the concentrations of the eight studied minerals in maize grown with four irrigation treatments suggests that there were different relationships with the soil water in different uptake directions and transport mechanisms. It is likely that soil drought stress improves to a certain extent the uptake routes and/or transport mechanisms of $\mathrm{K}, \mathrm{Mg}, \mathrm{Fe}, \mathrm{Mn}, \mathrm{Cu}$, and $\mathrm{Zn}$ [3]. According to Ferreria et al. [28], when serious soil water deficit occurs, all ions become less mobile because of the replacement of water by air in the pore spaces, thereby increasing soil tortousity and the strength of ion retention by the soil colloids, resulting in decreased absorption. On the other side, according to these authors, 
Table 4. Effect of different irrigation levels on the concentrations (mg/kg dry weight) of select maize grain microminerals.

\begin{tabular}{|c|c|c|c|c|c|}
\hline Years & $\begin{array}{l}\text { Irrigation } \\
\text { levels }\end{array}$ & $\mathrm{Fe}$ & $\mathrm{Mn}$ & $\mathrm{Cu}$ & $\mathrm{Zn}$ \\
\hline \multirow{4}{*}{2012} & $\mathrm{I}_{100}$ & $22.6 \mathrm{c}^{*}$ & $8.7 \mathrm{bc}$ & $6.0 \mathrm{a}$ & $20.8 \mathrm{bc}$ \\
\hline & $\mathrm{I}_{75}$ & $24.9 \mathrm{a}$ & $10.5 \mathrm{a}$ & $4.6 \mathrm{c}$ & $25.9 \mathrm{a}$ \\
\hline & $\mathrm{I}_{50}$ & $23.6 \mathrm{~b}$ & $9.6 \mathrm{~b}$ & $4.4 \mathrm{~d}$ & $22.4 \mathrm{~b}$ \\
\hline & $\mathrm{I}_{0}$ & $22.5 \mathrm{c}$ & $8.1 \mathrm{c}$ & $5.2 \mathrm{~b}$ & $21.0 \mathrm{c}$ \\
\hline \multirow{4}{*}{2013} & $\mathrm{I}_{100}$ & $23.4 \mathrm{~b}$ & $8.9 \mathrm{~b}$ & $5.9 \mathrm{a}$ & $21.7 \mathrm{~b}$ \\
\hline & $\mathrm{I}_{75}$ & $24.6 \mathrm{a}$ & $10.1 \mathrm{a}$ & $5.1 \mathrm{c}$ & $27.8 \mathrm{a}$ \\
\hline & $\mathrm{I}_{50}$ & $23.2 \mathrm{bc}$ & $9.4 \mathrm{ab}$ & $4.3 \mathrm{~d}$ & $21.2 \mathrm{~b}$ \\
\hline & $\mathrm{I}_{0}$ & $21.9 \mathrm{c}$ & $7.9 \mathrm{c}$ & $5.3 \mathrm{~b}$ & $19.1 \mathrm{c}$ \\
\hline \multirow{4}{*}{2014} & $\mathrm{I}_{100}$ & $23.0 \mathrm{~b}$ & $8.0 \mathrm{c}$ & $6.3 \mathrm{a}$ & $22.4 \mathrm{~b}$ \\
\hline & $\mathrm{I}_{75}$ & $24.8 \mathrm{a}$ & $9.9 \mathrm{a}$ & $5.3 \mathrm{~b}$ & $23.3 \mathrm{a}$ \\
\hline & $\mathrm{I}_{50}$ & $22.9 \mathrm{~b}$ & $9.3 \mathrm{ab}$ & $4.6 \mathrm{c}$ & $21.4 \mathrm{c}$ \\
\hline & $\mathrm{I}_{0}$ & $21.3 \mathrm{c}$ & $8.7 \mathrm{~b}$ & $5.3 \mathrm{~b}$ & $18.6 \mathrm{~d}$ \\
\hline \multirow{4}{*}{$\begin{array}{c}\text { 3-year } \\
\text { average }\end{array}$} & $\mathrm{I}_{100}$ & $23.0 \mathrm{bc}$ & $8.5 \mathrm{c}$ & $6.1 \mathrm{a}$ & $21.6 \mathrm{~b}$ \\
\hline & $\mathrm{I}_{75}$ & $24.2 \mathrm{a}$ & $10.2 \mathrm{a}$ & $5.0 \mathrm{~b}$ & $25.7 \mathrm{a}$ \\
\hline & $\mathrm{I}_{50}$ & $23.2 \mathrm{~b}$ & $9.4 \mathrm{~b}$ & $4.4 \mathrm{~d}$ & $21.7 \mathrm{~b}$ \\
\hline & $\mathrm{I}_{0}$ & $21.9 \mathrm{c}$ & $8.2 \mathrm{c}$ & $4.9 \mathrm{c}$ & $19.6 \mathrm{c}$ \\
\hline
\end{tabular}

${ }^{*}$ Means followed by similar letters in each column are not significantly different as statistically $(P \leq 0.05)$.

when there is less plant growth due to severe water deficit, the content of these nutrients in plant tissue may increase. Under soil moisture deficit, there is a reduction of minerals once the protein synthesis decreases in this condition [29]. On the other hand, in response to drought stress many minerals are necessary for the synthesis of proteins responsible for antioxidant activity [30].

Maize has been the basis of the human diet since ancient times and an important source of certain minerals, especially in developing countries [29]. The low concentrations of essential microminerals in cereal grains and other crops contribute to the problem of micronutrient malnutrition. For example, almost half of the world's population is at risk of inadequate $\mathrm{Zn}$ intake [31]. Zhao et al. [20] reported that the lower (nutritional value):(caloric value) of crops under agronomic practices including water supply will aggravate the micronutrient malnutrition problem worldwide.

Results of our research indicate that mineral contents in the grains of maize were greatly affected by irrigation, which showed that nutrient concentrations $(\mathrm{Mg}, \mathrm{Fe}, \mathrm{Mn}$, and $\mathrm{Zn}$ ) in maize grain were decreased by too high an irrigation level. Whereas mild water deficit (treatment $\mathrm{I}_{75}$ ) throughout the growing season was beneficial to mineral accumulation in maize grain, serious soil moisture deficit can lead to high decreases in grain yield of maize. As indicated above on irrigation water-applied effects, proper water conditions $\left(\mathrm{I}_{75}\right.$ treatment) over a growing season can be favorable to more mineral concentrations and higher yield in maize grain than the other.

\section{Correlation between Yield and Nutrients}

This correlation analysis is presented in Table 4 . A significant high-magnitude negative correlation was established between grain yield and starch content $(r=-0.71)$ and $\mathrm{Ca}$ concentration $(r=-0.70)$. The results indicate that if the yields decreased or increased, the maize grain starch content and $\mathrm{Ca}$ concentrations measured

Table 5. Correlations coefficients among yield and grain quality traits in maize.

\begin{tabular}{|c|c|c|c|c|c|c|c|c|c|c|c|c|}
\hline Traits & GY & GPC & GSC & GOC & K & P & Ca & Mg & Fe & Mn & Cu & $\mathrm{Zn}$ \\
\hline $\mathrm{GY}^{\mathrm{a}}$ & 1.00 & 0.27 & $0.71^{*}$ & 0.56 & 0.57 & -0.14 & $-0.70^{*}$ & 0.12 & $0.61^{*}$ & 0.55 & -0.45 & 0.52 \\
\hline $\mathrm{GPC}$ & & 1.00 & -0.27 & -0.30 & 0.46 & 0.43 & -0.42 & $0.63^{*}$ & 0.49 & 0.52 & 0.21 & 0.54 \\
\hline $\mathrm{GSC}$ & & & 1.00 & $-0.69^{*}$ & -0.40 & -0.18 & $0.76^{*}$ & -0.43 & $-0.72^{*}$ & $-0.73^{*}$ & 0.41 & $-0.73^{*}$ \\
\hline $\mathrm{GOC}$ & & & & 1.00 & 0.16 & -0.07 & -0.38 & -0.06 & 0.37 & 0.30 & -0.50 & 0.30 \\
\hline $\mathrm{K}$ & & & & & 1.00 & 0.00 & $-0.64^{*}$ & 0.34 & 0.43 & 0.24 & 0.35 & 0.40 \\
\hline $\mathrm{P}$ & & & & & & 1.00 & -0.45 & $0.73^{*}$ & 0.39 & 0.50 & 0.31 & 0.47 \\
\hline $\mathrm{Ca}$ & & & & & & & 1.00 & $-0.63^{*}$ & $-0.75^{*}$ & $-0.75^{*}$ & 0.03 & $-0.74^{*}$ \\
\hline $\mathrm{Mg}$ & & & & & & & & 1.00 & $0.74^{*}$ & $0.76^{*}$ & 0.22 & $0.79^{*}$ \\
\hline $\mathrm{Fe}$ & & & & & & & & & 1.00 & $0.93^{*}$ & -0.26 & $0.97^{*}$ \\
\hline $\mathrm{Mn}$ & & & & & & & & & & 1.00 & -0.38 & $0.90^{*}$ \\
\hline $\mathrm{Cu}$ & & & & & & & & & & & 1.00 & -0.14 \\
\hline $\mathrm{Zn}$ & & & & & & & & & & & & 1.00 \\
\hline
\end{tabular}

${ }^{\mathrm{a}} \mathrm{GY}$ : grain yield (t/ha), GPC: grain protein content $(\mathrm{g} / \mathrm{kg})$, GSC: grain starch content $(\mathrm{g} / \mathrm{kg}), \mathrm{GOC}$ : grain oil content $(\mathrm{g} / \mathrm{kg})$

*Significant at 0.05 probability level 
an additional increase or decrease. There was also a significant positive correlation between grain yield and $\mathrm{Fe}$ concentration $(r=0.61)$. The maize grain protein content in the present study demonstrated a positive correlation with $\mathrm{Mg}$ concentration $(r=0.63)$. A significant negative correlation was noted between starch content, on the one hand, and oil content $(r=-0.69)$ and the concentrations of $\mathrm{Fe}(r=-0.72), \mathrm{Mn}(r=-0.73)$, and $\mathrm{Zn}(r=-0.73)$. There was a significant high-magnitude positive correlation between the maize grain starch content and the concentration of $\mathrm{Ca}(r=0.76)$. The present study also revealed a significant negative correlation between maize grain concentration of $\mathrm{Ca}$, on the one hand, and $\mathrm{K}(r=-0.64), \mathrm{Mg}(r=-0.63)$, $\mathrm{Fe}(r=-0.75), \mathrm{Mn}(r=-0.75)$, and $\mathrm{Zn}(r=-0.74)$. However, there was also a significant high-magnitude positive correlation between the concentrations of $\mathrm{Mg}$ and $\mathrm{P}$ $(r=0.73), \mathrm{Fe}(r=0.74), \mathrm{Mn}(r=0.76)$, and $\mathrm{Zn}(r=0.79)$. The highest-magnitude correlation was established between $\mathrm{Fe}$ and $\mathrm{Mn}(r=0.93), \mathrm{Fe}$ and $\mathrm{Zn}(r=0.97)$, and $\mathrm{Mn}$ and $\mathrm{Zn}(r=0.90)$. The present research, similar to a number of other studies, revealed a strong positive correlation between cereal grain concentrations of $\mathrm{Ca}$, $\mathrm{Mg}, \mathrm{Fe}$, and $\mathrm{Zn}$, which suggests that measures aimed at increasing the concentration of one can also increase those of other elements [27]. The present study did not establish a significant correlation between the maize grain concentration of $\mathrm{Cu}$ and the yield and composition of macro- and microelements.

\section{Conclusions}

The impact of irrigation level on grain yield and nutritional components varied between the study years. The climatic differences had a significant impact on yield and chemical compositions of maize grains. The results showed that it was impossible to grow maize with a water deficit without a significant decrease in grain yield. In addition, nutritional quality depended on drought severity; as the soil water deficit increased (irrigation level decreased), maize grain nutrient losses were higher. However, starch content and $\mathrm{Ca}$ concentration had the opposite response to increasing drought stress. Limited water resources necessitate consideration of deficit irrigation of large surfaces. As such, a $25 \%$ water deficit $\left(\mathrm{I}_{75}\right)$ is acceptable for maize farming in Vojvodina, on silty clay soils, and other ecologically similar regions. The results of this research might be conducive to increasing yields and improving the nutritional quality of maize grain in the studied region and neighboring countries with similar soil and climate conditions.

\section{Acknowledgements}

This work was supported by research project III 43009 funded by the Serbian Ministry of Education, Science, and Technological Development.

\section{References}

1. OLESEN J.E., TRNKA M., KERSEBAUM K.C., SKJELVÅG A.O., SEGUIN B., PELTONEN-SAINIO P., MICALE F. Impacts and adaptation of European crop production systems to climate change. Eur. J. Agron., 34, 96, 2011.

2. FOROUD N., MÜNDEL H.H., SAINDON G., ENTZ T. Effect of level and timing of moisture stress on soybean plant development and yield components. Irrigation Sci., 13 (4), 149, 1993

3. GE T.D., SUI F.G., NIE S., SUN N.B., XIAO H., TONG C.L. Differential responses of yield and selected nutritional compositions to drought stress in summer maize grains. J. Plant Nutr., 33, 1811, 2010.

4. THITISAKSAKUL M., JIMENEZ R.C., ABIAS M.C., BECKLES D.M. Effects of environmental factors on cereal starch biosynthesis and composition. J. Cereal Sci., 56, 67, 2012.

5. TARIGHALESLAMI M., ZARGHAMI R., MASHHADI A.B.M., OVEYSI M. Effects of drought stress and different nitrogen levels on morphological traits of proline in leaf and protein of corn seed (Zea mays L.). Amer-Eurasian J. Agri. Environ. Sciences, 12, 49, 2012.

6. SEVIK H., CETIN M. Effects of water stress on seed germination for select landscape plants. Pol. J. Environ. Stud., 24 (2), 689, 2015.

7. YIGIT N., SEVIK H., CETIN M., KAYA N. Determination of the effect of drought stress on the seed germination in some plant species. In: Water Stress in Plants; Rahman I.M., Begum Z.A., Hasegawa H., Eds., Rijeka, Croatia, InTech, 43, 2016.

8. CETIN M. Landscape Engineering, Protecting Soil, and Runoff Storm Water. In: Advances in Landscape Architecture - Environmental Sciences; Ozyavuz M., Ed., InTech, Open Science - Open Minds, 697, 2013.

9. BROOKS R.M., CETIN M. Water susceptible properties of silt loam soil in subgrades in South West Pennsylvania. Int. J. Modern Eng. Res., 3 (2), S. No: 57, 944, 2013.

10. AKINYELE I.O., SHOKUNBI O.S. Concentrations of $\mathrm{Mn}, \mathrm{Fe}, \mathrm{Cu}, \mathrm{Zn}, \mathrm{Cr}, \mathrm{Cd}, \mathrm{Pb}$, Ni in selected Nigerian tubers, legumes and cereals and estimates of the adult daily intakes. Fod Chemistry, 173, 702, 2015.

11. WANG X., LU W., XU Y.J., ZHANG G., QU W., CHENG W. The positive impacts of irrigation schedules on rice yield and water consumption: synergies in Jilin Province, Northeast China. Int. J. Agr. Sustain., 14, 1, 2016.

12. AOAC. Official methods of analysis of the Association of Official's Analytical Chemists, $17^{\text {th }}$ Ed, Washington, DC. 2002.

13. International Standard: ISO 10520. Determination of starch content - Ewers polarimetric method. 1997.

14. KRESOVIĆ J.B., GAJIĆ A.B., TAPANAROVA Đ.A., PEJIĆ S.B., TOMIĆ P.Z, VUJOVIĆ S.D., ŽIVOTIĆ B.LJ. Effects of deficit irrigation on grain yield and ear characteristics of maize. J. Agr. Sci., 60, 419, 2015. (In Serbian, Abstract in English).

15. DOLFERUS R., JI X., RICHARDS R.A. Abiotic stress and control of grain number in cereals. Plant Sci., 181, 331, 2011.

16. BHIMIREDDY P., MALLAREDY M., SUBBAIAH G., CHANDRA SEKHAR K., VISHNU VARDHAN REDDY D., RAVINDRA BABU P. Perfomance of no-till maize under drip-fertigation in a double cropping system in semi arid Telangana state of India. Maydica, 61, 1, 2017. 
17. AYDINSAKIR K., ERDAL S., BUYUKTAS D., BASTUG R., TOKER R. The influence or regular deficit irrigation applications on water use, yield, and quality components of two corn (Zea mays L.) genotips. Agr. Water Manage., 128, 65, 2013.

18. ERTEK A., KARA B. Yield and quality of sweet corn under deficit irrigation. Agr. Water Manage., 129, 138, 2013.

19. CAI Y.X., WANG W., ZHU Q.S. Effects of water stress on nutrient quality and accumulation of protein in rice grains. Chin. J. Plant Ecol. 31, 536, 2007.

20. ZHAO C., HE M., WANG Z., WANG Y., LIN Q. Effects of different water availability at post-anthesis stage on grain nutrition and quality in strong-gluten winter wheat. CR Biol., 332, 759, 2009.

21. LU D., CAI X., ZHAO J., SHEN X., LU W. Effects of drought after pollination on grain yield and quality of fresh waxy maiz. J. Sci. Food Agr., 95, 210, 2015

22. LIU L., KLOCKE N., YAN S., ROGERS D., SCHLEGEL A., LAMM F., WANG D. Impact of deficit irrigation on maize physical and chemical properties and ethanol yield. Cereal Chem., 90, 453, 2013.

23. ALI Q., ASHRAF M., ANWAR F. Seed composition and seed oil antioxidant activity of maize under water stress. J. Am. Oil Chem. Soc., 87 (10), 1179, 2010.

24. YAZAR A., GÖKÇLI F., SEZEN S.M. Corn yield response to partial rootzone drying and deficit irrigation strategies applied with drip system. Plant Soil Environ., 55, 494, 2009.

25. OKTEM A. Effect of water shortage on yield, and protein and mineral compositions of drip-irrigated sweet corn in sustainable agricultural systems. Agr. Water Manage., 95, 1003, 2008.
26. NAN Z., LI J., ZHANG J., CHENG G. Cadmium and zinc interactions and their transfer in soil-crop system under actual field conditions. Sci. Total Environ., 285, 187, 2002.

27. PAIVA C.L., QUEIROZ B., V.A.V., SIMEONE M.L.F., SCHAFFERT R.E., OLIVEIRA A.C., SILVA C.S. Mineral content of sorghum genotypes and the influence of water stress. Food Chemistry, 214, 400, 2017.

28. FERREIRA V.M., MAGALHAES P.C., DURAES F.O.M., VASCONCELLOS C.A., ARAUJO NETO J.C. de. Acúmulo e distribuição de macronutrients em dois hibridos duplos de milho, em função da disponibilidade de águ no solo. Rev. Bras. Milho Sorgo, 7, 1, 2008.

29. QUEIROZ V.AV., SILVA C.S., MENEZES C.B., SCHAFFERT R.E., GUIMARĂES F.F.M., GUIMARĂES L.J.M., GUIMARĂES P.E.O., TARDIN F.D. Nutritional composition of sorghum (Sorghum biocolor L.) Moench] genotypes cultivated without and with water stress. J. Cereal Sci., 65, 103, 2015.

30. JOGAIAH S., GOVIND S.R., TRAN L.S.P. Systems biology-based approaches toward understanding drought tolerance in food crops. Crit. Rev. Biotechnol. 33 (1), 23, 2013.

31. BROWN K.H., WUEHLER S.E. (Eds.). Zinc and human health: The results of recent trials and implications for program interventions and research, Micronutrient initiative. Ottawa. 2000. 